\title{
STATUS PERSENTASE TUTUPAN KARANG SCLERACTINIA DI PULAU BUNAKEN (TAMAN NASIONAL BUNAKEN) DAN DI PANTAI MALALAYANG, PESISIR KOTA MANADO
}

\author{
(The Status of Percentage Coverage of Scleractinian Coral in The Bunaken Island \\ (Bunaken National Park) and in Malayang Beach, Manado City Coastal Area)
}

\section{Emma Arny Caroles ${ }^{1 *}$, Janny D. Kusen ${ }^{1}$, Georis F. Kaligis ${ }^{1}$}

1. Program Studi Ilmu Kelautan Fakultas Perikanan dan Ilmu Kelautan Universitas Sam Ratulangi, Manado.

*e-mail: arny.caroles@yahoo.com

\begin{abstract}
Scleractinian coral or stone coral constitute of hermatypic coral therefore. In this case the determining of scleractinian coral status became an important part and very determinable of ecologically and economically roles of coral reefs ecosystem. One of the important parameter to know the scleractinian corals condition is the coverage percentage in the field. The research was carried out by quantititative descriptive method, whereas data were gathered by LIT (Line Intercept Transect) and analyzed by Coverage Percentage after analyzed by benthic life form. The environment parameters such as salinity, water temperature and visibility were measured.The research result has been shown that the status of coverage percentage at Malalayang beach, Manado in the 'poor' category, especially in 3 and 5 meter depths that was in the range between $0-24,9 \%$, although at 10 meter depth th only 'good' category, at the range between $50-69,9 \%$.Whereas in Bunaken Island research site in both sites, in the southern site at Fukui Station and in the northern site at Pangalisang Station mostly the results has been shown 'excellent' in the range $>70 \%$ of scleractinin coral coverage percentage. Therefore, it has been known that the condition of scleractinian coral in the protection or conservation area relatively more good condition than the scleractinian coral at open area for public where the intensity of anthropogenic activities presure were relativelyhigh.
\end{abstract}

Keywords : scleractinian, conservation, non-conservation

Karang scleractinia atau karang batu merupakan karang pembentuk terumbu. Sehingga penentuan status kondisi karang batu menjadi bagian penting dan sangat menentukan peran ekologis dan ekonomis ekosistim terumbu karang. Salah satu parameter untuk mengetahui kondisi karang batu yaitu persentase tutupan di alam. Penelitian dilakukan menggunakan metode deskriptif kuantitatif dengan tehnik pengambilan data dengan menggunakan LIT (Line InterceptTransect) yang selanjutnya dianalisis dengan Persentase Tutupan Karang setelah data diolah dengan 'benthic life form'. Parameter lingkungan berupa salinitas dan suhu air serta kecerahan juga diukur. Hasil penelitian menunjukkan bahwa persentase tutupan di perairan pantai Malalayang Kota Manado dalam status kategori 'poor' (Buruk) khususnya di kedalaman 3 dan 5 meter yaitu pada kisaran antara 0-24,9\%, sekalipun pada kedalaman 10 meter hanya kategori 'good' (Baik), pada kisaran antara 50 - 69,9\%.. Sedangkan di stasiun penelitian Pulau Bunaken baik di bagian selatan yaitu Stasiun Fukui dan bagian utara pulau yaitu Stasiun Pangalisang hasilnya sebagian besar 'excellent' (sangat baik) yaitu dalam kisaran $>70 \%$ persentase tutupan karang batunya. Dengan demikian diketahui bahwa karang yang berada di kawasan yang dilindungi atau konservasi masih relatif lebih baik kondisinya daripada karang yang berada di kawasan terbuka untuk umum sehingga tekanan kegiatanantropogenik intensitasnya relatif tinggi.

Kata kunci :scleractinia, konservasi, non-konservasi 


\section{PENDAHULUAN}

Terumbu karang sebagai suatu ekosistem terdapat di hampir semua perairan pesisir di Indonesia. Karang merupakan averteberata laut dari ordo Scleractinia yang masuk pada kelas Anthozoa dalam filum Cnidaria (Veron, 1986). Secara tipikal atau yang cukup mencolok terlihat bahwa aveteberata ini hidup dalam suatu koloni yang terhimpun oleh individu-individu polip yang identik. Jadi polip merupakan individu fauna karang yang dalam koloni terhubungkan satu dengan yang lain. Koloni ini sangat penting sebagai pembentuk terumbu karang dan umumnya menempati lautan tropis Karang batu yang diketahui juga sebagai pembentuk utama terumbu karang, mempunyai peranan yang sangat penting dalam penyediaan oksigen ke dalam perairan di sekitarnya melalui proses fotosintesis dengan microalga simbiosis yang hidup dalam jaringan tubuh karang.

$$
\text { Berbagai macamteknik }
$$
eskploitasi yang dilakukan terhadap terumbu karang sebagai suatu sumber daya dewasa sekarang ini telah dilakukan untuk memenuhi berbagai kebutuhan manusia, akan tetapi di sisi lain hal ini justru menjadi ancaman bagi kelangsungan terumbu karang. Kebutuhan hidup yang semakin tinggi untuk terpenuhi menjadi salah satu penyebab kerusakan terumbu karang seperti penangkapan ikan dengan cara yang tidak direkomendasikan seperti penggunaan bom dan racun, ataupun jaring yang dioperasikan di atas terumbu karang (Kusen, et al., 2016). Selain itu pembuatan tambak pada daerah mangrove menyebabkan kerusakan hutan mangrove yang juga berdampak pada terumbu karang, reklamasi, dan sebagainya. Faktor alami juga mempengaruhi dalam kerusakan terumbu karang seperti perubahan iklim, gempa bumi dan lainya. ialah:
1. Untuk mengetahui keberadaan persentase tutupan karang batu di Pulau Bunaken, Taman Nasional Bunaken dan pesisir Kota Manado..

2. Untuk mengetahui perbedaan persentase tutupan karang, lokasi non daerah konservasi di pantai Malalayang dan di daerah konservasi Pulau Bunaken, Taman Nasional Bunaken.

\section{METODE PENELITIAN}

\section{Waktu dan Lokasi Penelitian}

Penelitian ini berlangsung selama 4 (empat) bulan sejak bulan januari-april 2017. Penelitian dilakukan di 2 (dua) tempat yang berbeda yaitu: Di Pulau Bunaken (Gambar 1), Taman Nasional Bunaken masing-masing di Stasiun Fukui pada koordinat $1^{\circ} 36^{\prime} 44^{\prime \prime}$ LU dan $124^{\circ}$ 44' 22" BT dan Stasiun Pangalisang pada koordinat $1^{\circ} 36^{\prime} 23^{\prime \prime}$ LU dan $124^{\circ} 41^{\prime} 01^{\prime \prime}$ BT, serta Pantai Malalayang pada koordinat $1^{\circ} 27^{\prime} 37$, 08"LU dan 124 47' 03"BT, Kota Manado (Gambar 2). Pengamatan dilakukanterhadap karang (scleractinia) pada kedalaman $3 \mathrm{~m}, 5 \mathrm{~m}$, dan $10 \mathrm{~m}$ di daerah terumbu karang.

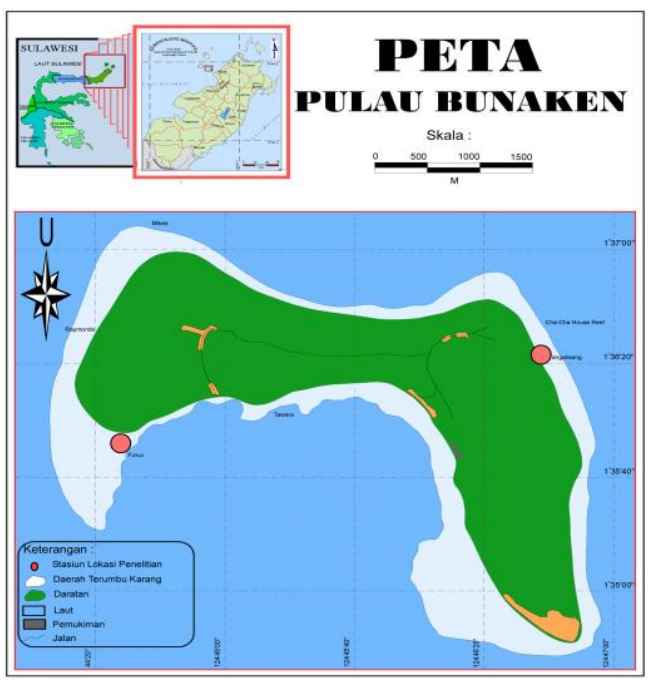

Gambar 1. Lokasi pengambilan sampel di pulau Bunaken, Taman Nasional Bunaken (Sumber: Taman Nasional Bunaken, 2010). 


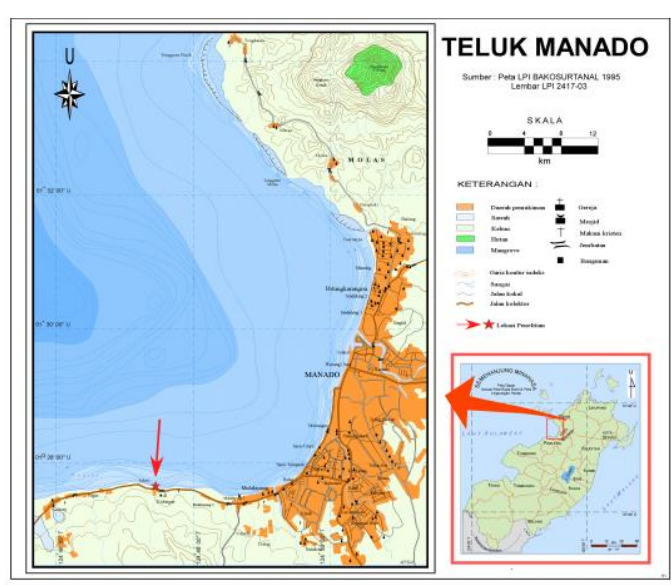

Gambar 2. Lokasi pengambilan sampel di pantai Malalayang, kota Manado

\section{Prosedur Kerja}

Teknik pengambilan data berupa pengamatan bawah air dengan menggunakan metode LIT (Line Intercept Transect) menurut kedalaman. Pada dasarnya cara atau metode ini menggunakan sebuah garis transek yang diletakkan sejajar garis pantai di atas koloni karang dan dicatat setiap bentuk pertumbuhan (Life form) yang dilewati serta mengidentifikasi genus karang tersebut. Pengambilan data dilakukan dengan mengamati dan mencatat bentuk pertumbuhan serta identifikasi jenis-jenis karang yang tepat berada pada garis transek sesuai dengan kategori life form yang sudah disediakan. Pengambilan data pada setiap lokasi penelitian dibagi atas 3 (tiga) tipe lokasi pengamatan berdasarkan kedalaman yaitu :

- Tipe dangkal, kedalaman $3 \mathrm{~m}$

- Tipe tengah, kedalaman $5 \mathrm{~m}$

- Tipe dalam, kedalaman $10 \mathrm{~m}$

\section{Analisa Data}

Analisis data diawali dengan identifikasi jenis karang, kemudian data dari LIT dianalisis dengan metode 'Life Form Category'. Secara umum data hasil identifikasi jenis dan persentase tutupan karang hidup dianalisis menurut formula Cox (1967) yang ditampilkan dalam bentuk tabel dan grafik. Untuk mengetahui yang ada di tiga stasiun tersebut, seperti dalam beberapa studi terumbu karang khusus mengenai persentase tutupan karang hidup menggunakan beberapa pendekatan dengan cara mengetahui persentase tutupan karang. Adapun rumus untuk mendapatkan Persentase Tutupan Karang (\%) diketahui dengan menggunakan rumus Cox (1967), yaitu sebagai berikut:

$$
\text { PTK }(\%)=\frac{\text { Total ukuran koloni }}{\text { Total ukuran transek }}
$$

Kemudian dengan mengacu pada Yap and Gomez (1984) mengkategorikan kondisi terumbu karang berdasarkan hasil persentase tutupan yaitu :

- Excellent (Sangatbaik): Jika "percent cover" $75-100 \%$

- Good (Baik) : Jika "percent cover" 50-74,9\%

- Fair (Cukup): Jika"percent cover" 2549,9\%

- Poor (Buruk): Jika "percent cover" $0-24,9 \%$

\section{HASIL DAN PEMBAHASAN}

\section{Tutupan Karang Menurut Kategori Benthic Life Form}

Tutupan karang hidup pada masing-masing memiliki persentase yang berbeda pada tiap kriteria kedalaman. Tutupan karang batu pada beberapa kedalaman yang berbeda di masing-masing stasiun memberikan gambaran secara khusus mengenai keberadaan status dan kondisi terumbu karang baik di Pantai Malalayang maupun di Pulau Bunaken.

\section{Tutupan Karang Batu di Stasiun Malalayang}

Persentase tutupan karang di Stasiun Malalayang menunjukkan bahwa pada kedalaman $3 \mathrm{~m}$ karang batu submassive (CS) dari kelompok Hard Coral Non-Acropora merupakan karang batu yang paling tinggi $(40,56 \%)$ pada kedalaman $10 \mathrm{~m}$ diikuti karang massive (CM) juga dari Non-Acropora di 
kedalaman $3 \mathrm{~m}$. Secara khusus persentase tutupan karang masingmasing di kedalaman $3 \mathrm{~m}$ hanya 18,84 $\%$, kedalaman $5 \mathrm{~m} \mathrm{21,26 \%}$ dan kedalaman 10 m 50,84 \% .

\section{Tutupan Karang Batu di Stasiun Fukui}

Tutupan karang batu di Stasiun Fukui dihimpun dari hasil persentase Hard Coral (Acropora) dan presentase Hard Coral (Non-Acropora) di sema kedalaman seperti yang terlihat dalam Tabel 4 di bawah ini. Persentase tutupan karang di Stasiun Fukui menunjukkan bahwa pada kedalaman $10 \mathrm{~m}$ karang batu branching (ACB) dari kelompok Hard Coral Acropora merupakan karang batu yang paling tinggi $(57,00 \%)$ pada kedalaman $10 \mathrm{~m}$ diikuti karang branching (ACB) juga dari Hard Coral Acropora di kedalaman $5 \mathrm{~m}$. Secara khusus persentase tutupan karang masing-masing di kedalaman $3 \mathrm{~m}$ hanya

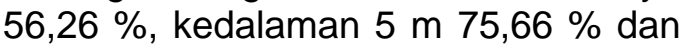

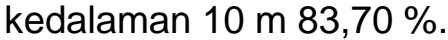

\section{Tutupan Karang Batu di Stasiun Pangalisang}

Tutupan karang batu di Stasiun Pangalisang dihimpun dari hasil persentase Hard Coral (Acropora) dan presentase Hard Coral (Non-Acropora) di semua kedalaman seperti yang terlihat dalam Tabel 6 di bawah ini. Persentase tutupan karang di Stasiun Pangalisang menunjukkan bahwa pada kedalaman $5 \mathrm{~m}$ karang batu branching (ACB) dari kelompok Hard Coral Acropora merupakan karang batu yang paling tinggi $(51,70 \%)$ m diikuti karang branching (ACB) juga dari Hard Coral Acropora di kedalaman $10 \mathrm{~m}$ sebesar $39,70 \%$. Secara khusus persentase tutupan karang masing-masing di kedalaman $3 \mathrm{~m}$ hanya $62,76 \%$, kedalaman $5 \mathrm{~m} 82,62 \%$ dan kedalaman $10 \mathrm{~m} 81,70 \%$.

\section{Status Kondisi Terumbu Karang}

Kondisi keberadaan karang batu (hard coral) sebagai indikator keberadaan dukungan kesehatan lingkugan hidup karang yang juga menjadi indikator status terumbu karang dapat dilihat pada (Tabel 7). Persentase total tutupan karang batu di masingmasing stasiun penelitian menunjukkan bahwa tutupan karang di kedalaman $3 \mathrm{~m}$ $(18,84 \%)$ dan $5 \mathrm{~m}(21,26 \%)$ di Stasiun Malalayang dalam kondisi 'poor' (buruk). Hal ini sangat memungkinkan karena pantai Malalayang merupakan kawasan non konservasi yang mudah dijangkau oleh kegiatan anthropogenik seperti wisata pantai termasuk berenang, selam permukaan (skin diving) dan selam bawah air (SCUBA diving). Juga terhubungkan dengan akses infrastruktur jalan raya yang memudahkan masuk ke kawasan pantai disitu. Kondisi ini berbeda dengan kondisi tutupan karang pada kedalaman $10 \mathrm{~m}(50,84 \%)$ di Stasiun Malalayang sekalipun dalam kategori 'good' (baik). Sangat berbeda dengan persentase tutupan di kawasan Taman Nasional Bunaken yaitu khususnya di Pulau Bunaken pada Stasiun Fukui (selatan Pulau Bunaken) dan Stasiun Pangalisang (utara Pulau Bunaken) yang relatif intensitas kunjungan rendah jika dibandingkan denhan pantai Malalayang. Pada masing-masing stasiun ini kategori persentase tutupan karang ialah Stasiun Fukui 3 m 56,26 \% dengan predikat kategori 'good' (baik), kedalaman $5 \mathrm{~m}$ 75,66 \% kategori 'excellent' (sangat baik), kedalman $10 \mathrm{~m}$ $83,70 \%$ kategori 'excellent' (sangat baik). Kondisi ini juga sama pada stasiun penelitian yang lokasinya berbeda yaitu Stasiun Pangalisang dimana semuan kedalaman yaitu 3 , 5, dan $10 \mathrm{~m}$, masing-masing dalam kategori 'excellent' (sangat baik) pada prosentase $62,76 \%$ (3 m), 82,62 \% (5 $\mathrm{m})$, dan $81,70 \%(10 \mathrm{~m})$. Kondisi dan situasi serta kategori yang didapatkan dari penelitian ini membuktikan bahwa kawasan konservasi seperti Taman 
Nasional Bunaken secara signifikan memberikan fungsi proteksi terhadap keberadaan karang (tutupan) dan kondisi terumbu karang agar fugsi dan peran secara ekologis dan ekonomis bisa maksimal.

\section{KESIMPULAN}

a. Persentase tutupan karang di Stasiun Penelitian Fukui dan Stasiun Penelitian Pangalisang di Pulau Bunaken, Taman Nasional Bunaken berada dalam kategori Sangat Baik (Excellent);

b. Persentase tutupan karang di Stasiun Penelitian Malalayang, pesisir Kota Manado berada dalam kategori Buruk (Poor);

c. Persentase tutupan karang batu di kawasan konservasi Taman Nasional Bunaken relatif masih lebi baik dari persentase tutupa karang di kawasan non-konservasi pantai Malalayang, pesisir Kota Manado.

\section{DAFTAR PUSTAKA}

Cox, G. W. 1967. Laboratory manual of generalecology.WMC Brown Company Publishers. Duquque. lowa.

Kusen, J.D., Lumingas, L.J., Rondo. M. 2016. Ekologi Laut Tropis. Penerbit FPIK, 379 hal.

Veron, J.E.N. 1986. Corals of Australia and The Indo Pacific. Angus and Robertso, Sydney Australia. $p$ 644.

Yap, H.T., Gomez, E,D, 1984. Growth of Acropora pulchra II. Responses of natural and transplanted colonies to temperature and day length. Mar. Biol. 81: 209-215. 